\title{
THE INFLUENCE OF PARENTS' ACTIVITIES IN THE SCHOOL AND PARENTS' COMMUNICATION THROUGH SOCIAL MEDIA ON EDUCATIONAL MANAGEMENT IN ISRAELI SCHOOLS
}

\author{
WPŁYW DZIAŁAŃ RODZICÓW W SZKOLE - BEZPOŚREDNICH \\ I ZA POŚREDNICTWEM MEDIÓW SPOŁECZNOŚCIOWYCH \\ - NA ZARZĄDZANIE SZKOŁĄ W IZRAELU
}

https://doi.org/10.34739/zn.2020.51.02

Ilan Ferster

Israel, Ort Kramim High School ORCID: 0000-0001-8773-9403; e-mail:ilan@kramin.ort.org.il

\begin{abstract}
Over the past few decades, reforms to the education system in Israel have allowed for greater involvement of parents and the school community in the activities at schools. Concurrently, the growing popularity of social media has created an ease of communication between parents and their children's educational management teams that has necessitated changes in the educational management of the school community. The purpose of this paper is to provide an overview of studies that examine the changing influence that parents' involvement in school activities and their communication on social media has on the role of educational management in Israeli schools. A comprehensive review of key publications was conducted to synthesize research findings. As will be shown, in the educational management of a school, which enables parental involvement and accommodates parental communications on social media, cooperation and coordination between parents, educational management and the school community, is likely to contribute to maintaining the required balance between positive involvement and overzealous interference.
\end{abstract}

Keywords: parental involvement, educational management, social media

Streszczenie: Rosnąca popularność nowych technologii komunikacyjnych zmieniła równowagę sił między rodzicami a zespołami zarządzającymi szkołą ich dzieci. Większa łatwość komunikacji spowodowała wzrost zaangażowania rodziców w szkole, a tym samym zmianę roli dyrektorów szkół w zarządzaniu interesariuszami szkoły. Działania rodziców w szkołach i ich komunikacja za pośrednictwem mediów społecznościowych spowodowały zmniejszenie uzależnienia rodziców od kierownictwa szkoły oraz jej kadry dydaktycznej. Celem artykułu jest zidentyfikowanie i wyjaśnienie ewolucji zaangażowania rodziców w zarządzanie szkołą. Kompleksowy przegląd literatury został wykorzystany do oceny zmieniającego się wpływu zaangażowania rodziców w szkole poprzez działania szkolne i media społecznościowe oraz wpływ, jaki wywarł na zarządzanie szkołą. Wzrost wpływu rodziców na zarządzanie szkołą spowodował wiele pozytywnych zmian, jednakże negatywne reakcje w mediach społecznościowych okazały się szkodliwe dla zarządzania szkołą i środowiska szkolnego. Stwierdzono konieczność nasilenia współpracy i wzajemnej koordynacji działań rodziców, kierownictwa szkoły oraz innych interesariuszy, aby osiągnąć wymaganą równowagę między pozytywnym zaangażowaniem a nadgorliwą ingerencją rodziców.

Słowa kluczowe: zaangażowanie rodziców, zarządzanie szkołą, media społecznościowe

\section{Introduction}

The influence of parents on the educational management of their children's schools has transformed over the years, with a shift in the balance of power in the schools, from a situation where parents were dependent on school management and the control of the teachers, to one where a certain level of control has been placed in the hands of both parents and the children themselves. The transition of power, brought about by reforms imposed within the educational systems, has redefined parents' involvement in activities in the schools and their influence on school management. In addition, new communication technologies have caused further changes in the schools and altered the manner in which they communicate with parents and the wider community (Zhao, 2012). The expansion of the internet and the increasing use of mobile technology have created additional communication channels that have altered the relationships that 
had previously existed between the parents, the students and the school administration and teachers (Patrikakou, 2016). With much of the interactive communication between parents and the educational management currently taking place on social media, rather than through face-toface interactions, changes in the dynamics and lines of communication have reshaped the role of educational management in the schools.

\section{Literature review}

In alignment with global changes within educational systems, parents have begun asserting their rights to influence their children's education at school (Fisher, Fridman, 2009), which has affected the role of the principal and the staff in managing the school. Traditionally, there was a clear separation between management of educational activities within the school and the opportunities for parentsto get involved in some capacity. The school would control the materials and activities that children were exposed to during school hours and parents generally would not interfere with school policy regarding these same activities (Frankenshtein, 1997). Currently, it seems that along with greater opportunities for parents' involvement in their children's education, and with parents taking a more active role in school activities, evolving communication technologies have expanded the possibilities for parents' involvement through social media, allowingthem to exert their influence on educational management. One consequence of using social media for communication has been changes in the dynamics between parents, educational management and teachers (Thompson, 2008).

Researchers have suggested a number of reasons for the changes in parents' involvement. Some changes have arisen due to the elevation in parents' education, the strengthening of the democratic process and the decrease in budgets to the education systems. Other factors that could account for greater involvement have been the vast choices offered for education programs, the wider competition and the over achievement of both parents and children (Golderberg, 1996). According to research conducted by Coley, Barton (2009), those parents whose children were more socially accepted, were more likely to be involved in the educational processes in the school. In addition, several background variables might influence parents' involvement, such as parents who hail from countries where parental involvement is the norm (Zill et al., 1993) or non-working moms, which would suggest upper-class families. It has been shown that parents who come from stable financial backgrounds often feel that they have the right and authority to influence educational decisions at their child's school.

The reform of the education system in Israel has led to changes in the level of involvement of parents in the governance of schools. Over time, "public education governance in Israel has been moving gradually from a quasi-social democratic mode to a neoliberal one" (Avigur-Eshel, Berkovich, 2018, p. 844). Following the establishment of the State of Israel, with the founding of the education system, the centralized bureaucracy placed all functions of the schools under state control. Within this structure, management took on a monocentric and paternalist style. During this period, parental involvement was limited. The transition to a neoliberal mode began in Israel in the 1980's, with drastic cuts to the budgets. Changes to practices at schools encouraged greater parental choice, legitimate parental involvement and the introduction of school-based management (Avigur-Eshel, Berkovich, 2018). As parents take on a more significant role in school governance, they are more likely to challenge decisions made by the school and the educational management and to become involved in issues that were previously reserved for educators. Furthermore, the boundaries between the schools and their external social environment are becoming more permeable, requiring the schools to seek new strategies to fulfill parents' expectations and increase their satisfaction. Maintaining a balance between the managerial control of the school and parental involvement has proved complex. Nevertheless, the gradual change of the schools in Israel to a social system, accompanied by parents' participation in school governance activities, has been shown to enhance the effectiveness of the schools (Nir, Bogler, 2012).

Following global changes to educational management leadership, in 2007, the Israeli Ministry of Education took steps to improve the education system through changes in the managerial role of school principals in Israel. Avney Rosha, the Israeli Institute for School Leadership was established and changes to the pedagogic and administrative role of school principals were introduced (Avney Rosha, 2009). The mission of the institute is to improve the education system through delegation of authority to school principals in Israel. The institute supports the principal's role in school leadership and recognizes that school leadership is the key to advancing the education system in Israel. The Institute is engaged in the training and professional development of all school principals and supervisors in Israel. The professional committee of the Avney Rosha institute has defined the role 
of the school principal as one of 'educational and pedagogical leadership'; for improving the education and learning of all the pupils in the school. In their report, the committee described four other managerial areas required of the principal, i) vision and change management, ii) managing teaching staff and their professional development, iii) focusing on the individual student, and iv) the management of schoolcommunity relations. The principal also has obligations to external authorities and must meet standards set by the Ministry of Education. Yet, the boundaries of the principal's role within the educational system have not been considered to be adequately defined (Avney Rosha, 2009).

According to a report presented by the Organization for Economic Cooperation and Development (OECD), (2012), parents have become a central influence on educational management. In the past, when necessary, parents would visit the school after setting up an appointment and would complain face-to-face to the appropriate authority. A full exploration of the effect that online interactions have had on face-toface relations has not occurred. Furthermore, it is not yet clear whether online interactions have limited such occurrences; or indeed whether these face-to-face relationships have been made more problematic by the greater use of online communications (Patrikakou, 2016). Currently, conflict between parents and the school may play out publicly on social media online. This can create many problems for the school, beginning with vexatious accusations and later, direct engagement with higher authorities to resolve the situation in a different manner. Other responses from the parents could lead to damaging claims against the school on social media, in order to gather support from other parents or just to mention the schools' name in order to tarnish their reputation. Educational management canchoose respond in various ways. The management could provide the parent with a solution to the problem in a respectable manner, which should ease matters and diffuse tensions Alternatively, the management could distance the parent from the school; althoughit has been shown that distancing a parent could exacerbate the situation and ultimately damage the reputation of the school (Fisher, Fridman, 2009).

Parental participation through school activities or communication with the schools using social media is usually a local phenomenon, where the parents influence school-related processes. To further our understanding of the influence that parents and the school community may have on the school's educational management, this review will focus on studies examining the effect which parents' activities, and their use of social media in
Israel has had on the role of the educational management and the school staff.

\section{Methodology}

Following reforms in the Israeli education system, parents' involvement in their children's schools has undergone changes. The objective of the study is to examine the affect that parents' involvement in the school through school activities and the influence their communication with the schools using social media has on educational management in Israeli schools. This review provides an overview of studies that have examined the changing influence that parents' involvement in the school has had on educational management. A review of published research was conducted to identify and characterize the findings concerning key aspects of parental involvement in Israeli schools. The objective of the search was to identify relevant literature addressing two aspects of parental involvement in Israeli schools that influence educational management: a) parents' activities in the school and b) parents' communication through social media.

An electronic search was conducted to identify all relevant research in English. The populations of interest for the review were parents, teachers and principals. The interventions were the parents' activities in the schools and the parents' communication through social media. The outcome of the review was an assessment on the influence on educational management. The search focused on research pertaining to schools in Israel. In addition to the electronic database search, a search for relevant grey literature was also conducted and relevant reports and articles were included in the review. Based on citation titles and abstracts, articles were included in the review when they were considered relevant to the research topic. Literature addressing the influence of parental involvement on educational management in Israeli schools is limited.

Publication of studies that related to parental involvement and the use of parental communications on social media in Israeli schools were included in the review and the results were summarized descriptively. The sesults of this review can be used to identify and summarize the current situation in Israeli schools and provide information that is conducive for educational management decision-making.

\section{Findings and Discussion}

In Israel, following organizational changes that have been enacted over the years to the Israeli educational system, the school systems are transforming from organizational structures that 
are strictly hierarchical, with the principal at the helm, into management systems that are less centralized. In alignment with the transformation, the role of educational management leadership in the management of schools and their management practices are changing. While in the past the role of the principal had been to serve as teacher and educator, and at a later stage, as the administrative director and leader of teaching processes, more recently, the principal's role has shifted to a focus on professional educational leadership (Bibu, Saris, 2017). Students have become the focus of educational processes, where once they had been positioned at the bottom of school hierarchical structures (Oplatka, 2007). In educational management, the school principal is accorded a leadership role in promoting student education and driving continuous improvement in the educational organization (Blau, Presser, 2013). They may also be the driving force in determining school policies that relate to managing parents' involvement, such as nurturing an interest in the management of the school so as to increase registration for the school and to maintain the school's reputation (Mashiach, 2013).

In addition, the engagement of parents with their children's education encompasses all attitudes and activities by which the parents may engage with the school (Barr, Saltmarsh, 2014). In Israel, under the earlier centralized educational system, parents had limited control over educational processes and school activities. Introducing greater parental involvement in the schools requires parents to increase their participation in educational and school activities (Erdreich, Golden, 2017).

The school environment also includes a wide range of additional stakeholders. Stakeholders have been described as those people or groups that affect or can be affected by the decisions taken by an organization, its policies and the overall functioning of the organization (Clarkson, 1995). In schools, the stakeholders may include, in addition to the parents, teachers, pupils, the Ministry of Education, the local municipality, and the educational community. In their position as school principals, following the reforms in the educational systems, the principals have taken on the management of the stakeholders. School principals create a vision for educational success that fulfills the demands of the state, as well as the needs of the school staff, the students, the parents and the entire school community (Brzozowski, Ferster, 2017). In the role of educational management leadership, the principal takes on a responsibility for dealing with all aspects of parental involvement that may affect the success and functioning of the school (Bibu, Saris, 2017).
Since the population in Israel is made up of individuals from widely diverse ethnic and cultural backgrounds, the education system in Israel is segregated into four main educational streams in order to cater for the different sectors of the population. There are two state secular streams, one catering for the Hebrew-speaking population and the other for Arabic-speaking residents. In addition, the other streams are focused on the religious communities, with one state religious Hebrew-speaking stream and one independent stream, for the ultra-orthodox-Hebrew-speaking population (OECD, 2016).

Studies conducted in Arabic-speaking schools in Israel indicate that parents are generally less involved than their Jewish counterparts, perhaps resulting from differences in school policy, culture and resource allocation (Arar et al., 2014). In the past, the perception amongst Arab parents had been that the management of educational institutions should be centralized, allowing for little intervention by the parents (Arar, Abu-Asbah, 2013). Nevertheless, the global trend of parental involvement in the schools has also affected the Israeli-Arab minority; and socio-cultural changes have led to an increase in interest amongst Arab parents to become involved in their children's schools (Arar et al., 2017). Among the changes noted has been a transformation from a traditional society to one where competition and ambition is rife. The decentralization of the educational systems has led to the delegation of managerial power (Arar et al., 2017) and the increase in parental involvement in the schools as a means of increasing the children's socio-economic mobility (Fisher, Kostelitz, 2015).

In a study conducted in three Junior High Schools in the Arab sector in northern Israel, one that was based on differing models of stakeholder management in order to advance the school and the pupils, Bibu, Saris (2017) compared how the principal effectively managed parental involvement in the school. They concluded that schools with clearstructured managerial models that relate to internal and external stakeholders, like the parents, achieved better outcomes. In their study of the three schools, it was shown that one of the reasons for attaining higher achievements in a school seemed to be that the principal was able to form relations with all of the relevant stakeholders in the school (Bibu, Saris, 2017). More specifically, parental involvement has been shown to be a contributing factor to the success of educational processes in the school and to their children's academic success. In addition, educational management may benefit from parental involvement and assistance in the schools. 
Since the transformation of the educational system in Israel, the effect of parents' use of social media to exert their influence has become more apparent. Parents have been granted greater control over the school's decision-making regarding new and non-educational aspects, like the school budget, resources distribution, the teaching staff and the school's goals and values; and parents may therefore feel it is their right to do as they please (Rosenblat, Peled, 2003). These perceptions have been supported by a local Israeli news source, which reported that some principals and teachers claimed that parents' involvement in social media had become a "battlefield" between the two parties over the control of the educational system. In the past few years, teachers have expressed their discontent with the situation, saying that confusion has been created between what may be described as "involvement" to that which may be attributed to "interfering". Many of the teachers were not willing to acknowledge such thoughts in public for fear of losing their job (Mashiach, 2013). Furthermore, in the balance of power between school management and parents, school systems have viewed parents and students as clients. A need has been created for the schools to satisfy their clients' wishes, resulting from the parents' growing power over school resources and the school's struggle to survive in a rapidly changing world (Almog-Bareket, Friedman, 2010).

However, parents' involvement in the school may not always be beneficial. Involvement in the school can be disadvantageous when a parent is not satisfied with the school policy or its decisions. In an environment where every situation can be exposed for all to witness, many parents turn to social media to express their discontentment with the school. Furthermore, where communication channels are open and accessible, instead of trying to communicate with the school directly, parents may quickly approach a higher authority in order to pressure the school management to change their decision, without looking at the possible consequences and likely outcomes. To avoid conflicts between educational management, teachers and parents, attempts have been to resolve public interaction on social media as quickly and as quietly as possible to avoid public criticism. The public battlefield of social media has compelled the management to act from what may be considered a weaker position in order to maintain their own positions and the school's reputation (Bourdieu, Wacquant, 1992).

In some situations, wherein most parents do not possess the knowledge needed to weigh in on school matters, especially issues like school budgets and staff dealings, over-involvement by the parents is likely to limit the schools' achievements and may denigrate the educational staff in the eyes of the students. The result may be that when a child witnesses his parents disrespecting teachers and dismissing a school authority on social media, they may perceive this behavior as acceptable, leading to acceptance by the child of disrespect of teachers and school management. Parents may believe they are acting appropriately and protecting their child, but over time, this contentious behavior may lead to negative outcomes rather than positive outcomes. In one such case at a public school in Israel, with the opening of a new school year at the school, parents and children were notified of a new school dress code. The dress code included specifications on the length of pants in school. Within several hours of being notified about the dress code, social media was full of frustrated parents expressing their dislike of this decision. The parents threatened to initiate a strike, claiming that the school had no business deciding on the length of the pants which their children were to wear. Some even said that this was discriminating for the girls, since the pant length specified was the same for boys and girls, and thus the girls would be unable to attend school with the shorter length of short pants to which they had been accustomed (Litman, 2014). In this situation, the parents believed that they had the right to decide about their child's dress code and appearance, and that they were fighting for their childrens rights. According to the Ministry of Education in Israel, schools have autonomy to decide on their dress codes, and the dress code should be set in agreement between management, teachers and pupils as appropriate to the values of the community. Parents had not been informed that that the school's management and staff had reached their decision after weighing in on the importance of proper dress code. In reaction to the protests and in an attempt to resolve the conflict, the management changed the dress codein order to diffuse the situation, but the decision ultimately undermined the school's authority even more; andit may be expected that school management would encounter greater issues in enforcing their authority in other situations (Litman, 2014).

Social media is an important tool for creating a direct connection between parents, school management and teachers. With advanced technology and social media integrated into day-to-day activities at school, currently, parents can be more openly involved in the schools' activities: in homework, in the educational programs and much more, through e-mail, Facebook, WhatsApp and the school web site at any time. Parents can engage with the school and ask questions or submit requests from their child's teachers throughout the day (Pomerantz et al., 
2007). In research conducted in 2015 that evaluated parents and teachers' viewpoints about social media interaction, it was found that both parties agreed that they were benefiting from such interactions on social media. In addition, they believed that positive outcomes, such as improved time management and increased availability were more beneficial to both sides than the negative outcomes that could result from parental involvement on social media (Noel et al., 2015). Technology can overcome the strictures of time, limited availability and the need to meet face to face, therefore expanding the possibilities for active involvement on the part of parents in the school using social media; thus contributing towards the creation of an environment of cooperation between parents and school management (Blau, Hameiri, 2017).

Parents' activities in the school and their use of social media for communication have created an ever-changing dynamic between parents and educational management. Parents' involvement in the school has brought about many positive changes that have required adaptation in the management role of principals and teachers. With the increasing use of social media, communications between the parents and the schools have become direct and rapid. As a result, these direct communications have introduced expectations for an almost immediate response from the school staff and educational management. Thus, parents' involvement in the school through communication channels like social media has not been without its shortcomings for the school, where even a single post on social media may have a major influence on the school's reputation, educational decisions and management issues. What may often begin as a single post on social media by a parent expressing a contentious attitude could create a snowball effect online that may have long-term repercussions for the school's future and on the positions of the educational management.

\section{Conclusions}

Parents have an obligation and the right to control and take care of their children's best interests in the education system. The reforms to the Israeli educational system have included parents as active stakeholders in the school system, with parents' interest in and involvement with the school taking on increased significance and having greater influence on the decisions taken by educational management. Cooperation between educational management and parents is needed to enable parents' involvement in school activities to be channeled to the benefit of the school organization.
The accessibility of online communication between parents, the educational management and the school staff has increased the influence that parents may have on educational management leadership and school processes. Nevertheless, publication of online responses to issues connected with the school requires careful consideration and steps to alleviate any ill effects to the school environment, including undesirable influences on educational management. By setting an example and responding on social media in ways that would not be construed as contentious, both parents and educational management could create an environment of respect and recognition of the value of school authority, while maintaining the rights of parents and children to become involved, to object to, and to request changes to school management policy. Productive parental input and constructive communications on social media between parents and educational management hold the potential to create an effective management environment that fulfills the needs of all its stakeholders.

\section{References}

Almog-Bareket, G., Friedman, Y. (2010). The Concept of a School's Organizational Values as Seen by Teachers and Students In Katz, M. (ed.) Studies in Educational Administration and Organization, 31, 31-56.

Arar, K., Abu-Asbah, K. (2013). Not just location: attitudes and perceptions of education system administrators in local Arab governments in Israel. International Journal of Educational Management, 27(1), 54-73.

Arar, K., Abu-Asbah, K., Abu Nasra, M. (2014). Arab parents' involvement in school reform in Israel. International Journal of Educational Reform, 23(2), 133-152.

Arar, K., Abu Nasra, M., Alshafi, H. (2017). Arab teachers' perception of parent involvement $(\mathrm{PI})$ : components and differences. IJEM, 32(3), 326-341.

Avigur-Eshel, A., Berkovich, I. (2018). Who 'likes' public education: social media activism, middle-class parents, and education policy in Israel. British Journal of Sociology of Education, 39(6), 844.

Avney Rosha. (2009). Perception of the Principal's Role in the State of Israel. Report by the Professional Committee to Formulate Policy Recommendations for the Ministry of Education. Israel. 
Barr, J., Saltmarsh, S. (2014). It all comes down to the leadership: The Role of the School Principal in Fostering Parent-School Engagement, Educational Management Administration \& Leadership, 42(4), 491-505.

Bibu, N., Saris, H. (2017). Managing the Process of Stakeholders Involvement in Junior HighSchool in Arab Sector in Israel, and Its Effect on Pupils, Teachers and Parents. Review of International Comparative Management / Revista de Management Comparat International, 18(2), 200.

Blau, I., Hameiri, M. (2017). Ubiquitous mobile educational data management by teachers, students and parents: Does technology change school-family communication and parental involvement? Education \& Information Technologies, 22(3), 1231.

Bourdieu, P., Wacquant, L. (1992). An Invitation to Reflexive Sociology Paperback. University of Chicago, Blackwell publish.

Brzozowski, M., Ferster, I. (2017). Educational Management Leadership: High School principal's management style and parental involvement in school management in Israel, in: Handbook of Research on Managerial Solutions in Non-Profit Organizations. IGI Global, 55-74.

Clarkson, M.B.E. (1995). A stakeholder framework for analyzing and evaluating corporate social performance. Academy of Management Review, 20(1): 92-117.

Coley, R.J, Barton, P.E. (2009). Policy Information Report: Parsing the Achievement Gap II. Educational Testing Service.

Erdreich, L., Golden, D. (2017). The cultural shaping of parental involvement: theoretical insights from Israeli Jewish parents' involvement in the primary schooling of their children. International Studies in Sociology of Education, 26(1), 51-65.

Fisher, Y., Fridman, Y. (2009). Parents and school: Interaction and involvement. Dapim: 47; 11-37.

Fisher, Y., Kostelitz, Y. (2015). Teachers' SelfEfficacy vs. Parental Involvement: Prediction and Implementation. Leadership \& Policy in Schools, 14(3), 279-307.

Frankenshtein, K. (1997). School without parents, honesty and equality. Tel-Aviv: "Poalim" publication.

Golderberg, D. (1996). Involvement and partnership in modern society. "lyonim" 29-38.
Litman, S. (2014). Why do schools forbid girls to wear short pants? Haaretz. https://www.haaretz. co.il/kids/.premium-1.2442225.

Mashiach, Y. (2013). Who is the land lord? Israel Today. https://www.israelhayom.co.il/article/ 140355

Nir, A.E., Bogler, R. (2012). Parental Involvement in School Govemance and Decision Making in Israel. Journal of School Public Relations. 33, pp. 216-236.

Noel, A., Redford, J., Stark, P. (2015). Parent and Family Involvement in Education, from the National Household Education Surveys Program of 2012. National center of national statistics.https://nces.ed.gov/pubs2013/20130 28rev.pdf

OECD. (2012). Education at a Glance 2012: Highlights, OECD Publishing, Paris. http://dx. doi.org/10.1787/eag_highlights-2012-en.

OECD. (2016), Education Policy Outlook: Israel. OECD Publishing, Paris. http://www.oecd.org/ israel/Education-Policy-Outlook-CountryProfile-Israel.pdf

Oplatka, Y. (2007). Foundation of Educational Management-Leadership and Administration in the Educational Organization. Haifa. Pardes. [Hebrew].

Patrikakou, E.N. (2016). Parent Involvement, Technology, and Media: Now What? School Community Journal, 26(2).

Pomerantz, E.M, Litwack S.D., Moorman, E.A. (2007). The How, Whom, and Why of Parents' Involvement in Children's Academic Lives: More Is Not Always Better. American educational research association, vol 77(3).

Rosenblat, Z., Peled, D. (2003). School ethical climate and parental involvement. Journal of Educational Administration 40(4): 349-367.

Thompson, C. (2008). Brave New World of Digital Intimacy. The New-York times, nytimes.com.

Zhao, Y. (2012). World class learners: Educating creative and entrepreneurial students. Thousand Oaks, CA: Corwin.

Zill, N., Morrison, D.R., Coiro, M.J. (1993). Long-term effects of parental divorce on parent-child relationships, adjustment, and achievement in young adulthood. Journal of Family Psychology, 7(1), 91-103. 